Original Research Paper

\title{
Pelatihan Pembuatan Dan Pengamatan Preparat Kromosom Profase I Meiosis Pada Guru-Guru Biologi Di Lombok Barat
}

\author{
I Gde Mertha ${ }^{1}$, I Wayan Merta ${ }^{1}$, Syamsul Bahri ${ }^{1}$, Ahmad Raksun ${ }^{1}$, A.A. Sukarso ${ }^{1}$

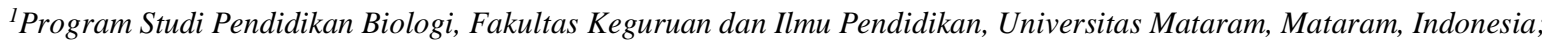

https://doi.org/10.29303/jpmpi.v3i2.1136

Sitasi: Mertha, I. G., Mertha, I. W., Bahri, S., Raksun, A \& Sukarso, A.A. (2021). Pelatihan Pembuatan Dan Pengamatan Preparat Kromosom Profase I Meiosis Pada Guru-Guru Biologi Di Lombok Barat. Jurnal Pengabdian Magister Pendidikan IPA 4(4)

\section{Article history}

Received: 02 Oktober 2021

Revised: 20 Oktober 2021

Accepted: 07 November 2021

*Corresponding Author: I Gde Mertha, Program Studi Pendidikan Biologi, Fakultas Keguruan dan Ilmu Pendidikan, Universitas Mataram, Mataram, Indonesia;

Email:

gdemertha19@gmail.com
Abstrak: Peran guru biologi yang profesional tidak saja mengajar materi di kelas tetapi juga dapat membimbing praktikum di laboratorium. Agar dapat membimbing praktikum dengan baik, guru biologi harus dibekali keterampilan teknik laboratorium khususnya pada kegiatan praktikum yang membutuhkan keterampilan dan kecermatan, seperti pembuatan sediaan kromosom meiosis dan observasi kromosom di bawah mikroskop. Karena keterbatasan keterampilan tersebut, praktikum pembuatan sediaan kromosom meiosis dan pengamatannya sangat terbatas dilakasanakan oleh guru-guru biologi di Lombok Barat, sehingga konsep genetika yang diberikan di sekolah belum terintegrasi dengan praktikumnya. Oleh sebab itu pelatihan teknik pembuatan preparat kromosom profase I meiosis yang dilanjutkan dengan pengamatannya perlu dikuasai guru-guru biologi. Kegiatan pengabdian ini telah dilaksanakan di SMA Negeri 1 Labuapi. Tujuan pengabdian ini adalah memberikan pelatihan mikroteknik pembuatan preparat mikroskopis squash sel-sel folikel testis untuk pengamatan kromosom meiosis dan melatih keterampilan observasi konfigurasi kromosom subfase profase I meiosis di bawah mikroskop. Metode yang digunakan pada kegiatan pengabdian ini adalah pelatihan dan unjuk kerja dalam bentuk praktik, yang dipadukan dengan ceramah, diskusi dan tanya jawab. Kegiatan praktik yang telah dilakukan, yaitu (1) praktik teknik koleksi dan penyimpanan folikel testis, (2) praktik teknik isolasi sel-sel folikel pada testis jangkrik Gryllus campestris, (3) praktik teknik squash sel-sel folikel untuk pembuatan peparat subfase profase I meiosis, (4) praktik observasi struktur khas konfigurasi kromosom pada subfase leptoten, zigoten, pakiten, diploten dan diakinensis dibawah mikroskop, dan (5) praktik visualisasi (pengambilan foto) kromosom subfase tersebut dibawah mikroskop. Hasil pelatihan menunjukkan bahwa (1) Pengabdian ini memberikan keterampilan sangat berharga bagi guru mitra dalam pembuatan preparat squash sel-sel folikel untuk pengamatan konfigurasi kromosom subfase profase I meiosis dan teknik visualisasinya dibawah mikroskop, (2) Kerja keras dan keseriusan guru mitra sangat mendukung kelancaran praktik pembuatan perangkat pembelajaran preparat squash sel-sel folikel testis, (3) Keterampilan yang diperoleh guru mitra dan preparat yang dihasilkan dari pelatihan ini meupakan modal berhaga untuk perencanaan dan pelaksanaan praktikum siswa pada materi genetika di sekolah.

Kata kunci: kromosom meiosis, propfase I, konfigurasi kromosom, diploten penurunan sifat (Rondonuwu, 1989). Sesuai Kurikulum Tingkat Satuan Pendidikan, materi genetika yang diajarkan pada jenjang SMA antara lain gen, DNA dan kromosom, replikasi DNA, sintesis protein; reproduksi sel (mitosis dan
Genetika sangat penting untuk dikuasai siswa di sekolah karena berhubungan erat dengan dasar 
meiosis), pewarisan sifat dan mutasi (Nusantari dan Abdul, 2013).

Konsep genetika pada materi bahan genetik tersebut dirasakan sulit oleh sebagian besar siswa karena bersifat abstrak (Corebima, 2009) dan jauh dari kehidupan sehari-hari siswa (Tsui \& Treagust, 2003 dalam Roini, 2013). Menurut Mahfudhillah et al. (2014) abstraknya materi genetika disebabkan objek yang dikaji memiliki ukuran mikroskopis, sulit diamati secara langsung tanpa bantuan alatalat canggih, banyak istilah-istilah yang harus dihafal dan dipahami, serta banyak menggunakan simbol-simbol yang dapat membuat peserta didik menjadi lebih sulit memahami konsep genetika. Contoh objek yang tidak dapat diamati secara langsung tanpa bantuan alat canggih misalnya struktur DNA, RNA, ribosom, proses transkripsi, translasi dan lain-lain. Dengan demikian siswa menganggap pembelajaran genetika melelahkan dan membosankan.

Menurut Mertens dan Hammersmith (2001) pembelajaran genetika pada materi yang abstrak karena berukuran mikroskopis dapat divisualisasikan dengan melakukan kegiatan pengamatan di laboratorium. Penggunaan mikroskop cahaya untuk pengamatan materi genetik kromosom sangat umum dilakukan pada penelitian dan praktikum genetika. Visualisasi kromosom dibawah mikroskop cahaya yang dilakukan pada kegiatan pengabdian Mertha et. al (2019) dan Mertha et al (2019) menunjukkan hasil yang bagus untuk pembelajaran genetika di sekolah. Untuk gambaran detail struktur kromosom yang menunjukkan variasi posisi kemasan DNA dapat dilakukan pembuatan kromosom banding (Cbanding dan fluorochrome-banding), yang keduanya dapat juga dimati dibawah mikroskop cahaya dengan spesifikasi khusus (Jones dan Rickards, 1991; Jahier et al., 1996). Gambaran jumlah, struktur, dan konfigurasi kromosom dapat digunakan dalam analisis hibrid hasil persilangan untuk memahami konsep genetika Mendel di sekolah (Singh, 1993; Suryo, 1995; Fauzi dan Corebima, 2016). Dengan adanya kemudahan pengamatan materi genetik dibawah mikroskop, maka dengan mengadakan kegiatan praktik laboratorium konsep genetika akan mudah dipahami siswa untuk mencapai kompetensi yang diharapkan. Oleh sebab itu dalam upaya pencapaian kompetensi genetika diperlukan pembelajaran yang tidak hanya berdasarkan konsep tetapi juga berbasis praktik.

Namun kenyataan yang terjadi di lapangan menunjukkan bahwa siswa kurang didorong untuk mengembangkan kemampuan berpikirnya melalui kegiatan praktik laboratorium, sementara guru-guru masih menerapkan metode mengajar secara tradisional yang berorientasi pada pengukuran kognitif saja (Hayat et al., 2011). Hasil penelitian Anggraeni (2011) dalam Nurmilasari (2013) mengemukakan bahwa masih banyak guru yang enggan melakukan praktikum karena guru kurang mampu melakukan praktikum. Menurut Rahman et al. (2004) kendala tersebut disebabkan karena guru kesulitan merencanakan percobaan, merumuskan tujuan, membuat lembar kerja siswa (LKS), mengelola praktikum dan menilai praktikum. Kondisi yang sama terjadi pada guru-guru biologi di Lombok Barat, berdasarkan hasil survey sejak tahun 2016 menunjukan bahwa mereka mengalami kesulitan pada teknik laboratorium sehingga pembelajaran genetika yang mereka terapkan belum terintegrasi dengan praktikum. Akibatnya, interaksi antara guru dengan siswa kurang, siswa tidak termotivasi, dan kesempatan siswa untuk berinteraksi langsung dengan materi genetik dibawah mikroskop sangat rendah. Hal ini menyebabkan pembelajaran menjadi tidak interaktif, siswa hanya sebagai objek dan bukan pelaku pembelajaran aktif berbasis praktik.

Pada organ kelamin (antera dan testis) terjadi pembelahan sel khusus dalam proses pembentukan gamet yang disebut meiosis (Rondonuwu, 1989). Proses meiosis berlangsung dalam dua tahap, yaitu meiosis I dan meiosis II, masing-masing tahap terbagi dalam lima fase, interfase, profase, metafase, anafase dan telofase, yang sama dengan proses mitosis. Menurut Kimball (1998) dan Woelaningsih (1999), profase I merupakan fase meiosis yang paling penting dan rumit. Fase ini terdiri dari beberapa langkah, yaitu: (a) Leptoten: ditandai oleh kromosom yang berbentuk benangbenang panjang mulai menebal dan ada yang lebih tebal disebut kromomer yang kelihatan seperti manik-manik pada seutas benang; (b) Zigoten: terjadi peristiwa dimana kromosom yang homolog berpasang-pasangan membentuk bivalen dan bergandengan disebut sinapsis; (c) Pakiten: fase utama penebalan kromosom dan mengganda menjadi dua kromatid; empat kromosom dalam satu bivalen disebut tetrad; (d) Diploten: keempat 
kromatid dalam satu bivalen bergerak memisah seolah-olah saling menolak menghasilkan pasangan-pasangan kromatid menjadi jelas, dapat terjadi pertautan pada beberapa tempat yang disebut kiasmata sehingga dapat terjadi pertukaran segmensegmen dari kromatid-kromatid yang homolog dan kejadian ini disebut pindah silang (crossing over); (d) Diakinensis: fase terakhir dari profase I dimana kromosom memendek dan menebal secara maksimal dan pertautan nampak jelas. Tahapantahapan subfase pada profase I tersebut berkaitan erat dengan DNA yang membentuk kromosom yang dapat divisualisasikan dengan mudah dan murah dibanding kromosom mitosis berdasarkan petunjuk yang disusun Darlington dan La Cour (1960), sehingga layak untuk digunakan praktikum berbasis mikroskop cahaya di sekolah.

Karena tahapan pengemasan DNA dan konfigurasi kromosom yang mudah diamati di bawah mikroskop cahaya, maka kromosom subfase profase I meiosis merupakan substansi genetik yang baik dalam memberikan gambaran untaian kemasan DNA yang membentuk kromatin (leptoten), kemasan DNA dalam bentuk kromatid yang melakukan duplikasi dan pemisahan (pakiten), dan gambaran detail pertukaran lengan kromosom yang menunjukkan proses pemutusan segmen DNA yang diikuti pertukaran diantara keduanya menghasilkan gamet rekombinan (pindah silang, crossing over pada diploten). Oleh sebab itu semua gambaran konfigurasi subfase profase I meiosis ini dapat menjadi sumber belajar yang efektif pada kajian bahan genetik.

Berdasarkan uraian di atas, pembuatan preparat dan pengamatan kromosom subfase profase I meiosis akan sangat menunjang peningkatan indikator pencapaian kompetensi dalam pembelajaran genetika di sekolah. Pembuatan kromosom meiosis jauh lebih singkat dan sederhana dibandingkan dengan pembuatan kromosom mitosis, dan dapat dikerjakan di sekolah. Namun kendala yang dihadapi guru-guru mitra dalam praktikum pembuatan slide kromosom tersebut adalah mereka belum memahami cara isolasi sel induk serbuk sari antera dan sel folikel testis, dan preparasi kelenjar tersebut menjadi preparat kromosom meiosis, serta identifikasi subfase kromosom dibawah mikroskop. Oleh sebab itu tujuan yang diharapkan dari kegiatan pengabdian ini adalah melakukan pendamping praktikum mikroteknik pembuatan preparat kromosom profase I meiosis dan melatih keterampilan observasi tahap subfase profase tersebut di bawah mikroskop. Sedangkan manfaat yang diharapkan dari kegiatan pengabdian ini adalah peningkatan keterampilan dan keahlian guru-guru biologi di Kabupaten Lombok Barat dalam pembuatan preparat meiosis dan kemampuan identifikasi konfigurasi kromosom untuk meningkatkan kualitas pembelajaran genetika.

\section{Metode}

Metode yang digunakan pada kegiatan pengabdian ini adalah pelatihan dan unjuk kerja dalam bentuk pendampingan praktek yang dikombinasikan dengan ceramah, diskusi dan tanya jawab. Kegiatan penyampaian materi pada pelatihan ini dilakukan secara klasikal, dimana semua peserta (guru-guru mitra) mengikuti materi yang disampaikan dengan cara ceramah, diskusi dan tanya jawab. Setelah selesai kegiatan penyampaian materi, selanjutnya dilakukan unjuk kerja praktik. Untuk memudahhkan dalam pengawasan kegiatan praktik, peserta pelatihan dibagi dalam kelomok-kelompok kecil. Pada saat praktek dilakukan pendampingan untuk memberikan bimbingan dan validasi pada kinerja praktik guru-guru mitra.

Kegiatan praktek pembuatan preparat kromosom tahap subfase I profase meiosis dilakukan pada sel-sel folikel testis jangkrik Gryllus campestris. Masing-masing peserta melakukan pengamatan preparat kromosom meiosis profase I yang telah selesai dikerjakan dibawah mikroskop dengan bimbingan pendampingan dari tim pengabdian. Pengamatan dilakukan mulai dari perbesaran lemah sampai perbesaran kuat. Perilaku atau konfigurasi kromosom yang diamati adalah leptoten, zigoten, pakiten, zigoten dan diakinensis.

Untuk mengetahui keberhasilan kegiatan pelatihan dilakukan evaluasi. Evaluasi atas kegiatan pelatihan pada pengabdian ini adalah apabila target dari program ini tercapai yaitu minimal $80 \%$ guru mitra dapat menghasilkan preparat kromosom meiosis profase I yang baik dan mampu menemukan fase-fase kromosom pada profase I dengan benar dibawah mikroskop. 


\section{Hasil dan Pembahasan}

Kegiatan pelatihan ini telah dilaksanakan dan telah behasil memberikan keterampilan kepada guru mitra tentang teknik pembuatan preparat squash testis untuk pengamatan meiosis dan visualisasi konfigurasi kromosom subfase profase I meiosis yang penting sebagai bahan praktikum genetika di sekolah. Dengan didorong semangat ingin tahu dan motivasi yang tinggi, peserta pelatihan sangat bersemangat melakukan praktikum sehingga berhasil menghasilkan produk pelatihan, yaitu (1) preparat (sediaan) squash sel-sel folikel testis Gryllus campestris untuk observasi kromosom profase I meiosis dan (2) Sel-sel folikel testis hasil isolasi untuk bahan pembuatan sediaan meiosis dalam praktikum. Respon yang sangat tinggi juga ditunjukkan guru mitra peserta pelatihan pada saat observasi preparat dibawah mikroskop cahaya. Melalui kegiatan pendampingan, guru mitra dapat menemukan semua subfase profase I meiosis dan berhasil melakukan dokumentasi sehingga dihasilkan tambahan luaran pelatihan, yaitu (1) visualisasi seri kromosom profase I meiosis dan (2) visualisasi detail konfigurasi (perilaku kromosom) Gryllus campestris subfase diploten dan diakinensis.

Isolasi sel-sel folikel testis dan preparasinya menjadi sediaan squash menambah kemampuan dan pengalaman guru mitra dalam teknik sitologi. Pemantauan terhadap unjuk kerja praktikum pembuatan preparat menunjukkan terjadi peningkatan keterampilan laboratorium guru mitra. Pada hari pertama pelatihan 50 persen peserta dapat membuat preparat yang benar, namun dengan latihan yang intensip pada hari kedua, diatas 85 persen peserta menjadi trampil membuat preparat. Hasil diskusi selama pendampingan observasi preparat menggambarkan bahwa telah terjadi perubahan signifikan pada kemampuan pemahaman peserta pelatihan terhadap materi kromosom meiosis profase I, sehingga bebeapa pertanyaan yang diberikan tim pengabdian dapat dijawab dengan benar. Penguasaan materi dan teknik laboratorium yang diperoleh guru mitra merupakan bekal yang berharga dalam perencanaan dan pelaksanaan praktikum genetika di sekolah.

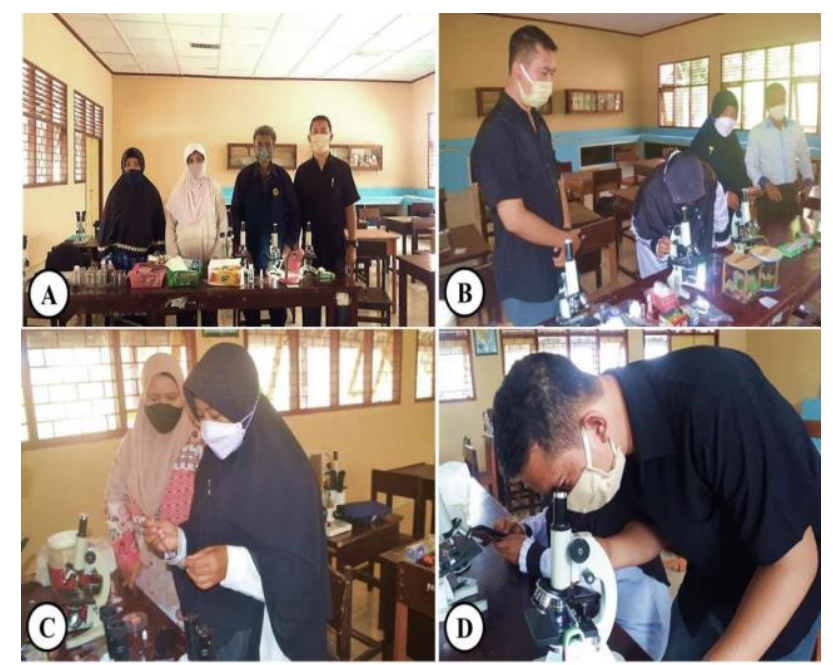

Gambar 1. Penyiapan bahan pelatihan dan pengamatan kromosom pofase I meiosis. A. Pengecekan alat dan bahan setelah penyampaian materi oleh tim pengabdian. B. Pengamatan preparat squash folikel untuk mencari semua subfase pada propfase I meiosis. C. Peserta pelatihan sedang menetesi folikel dengan stain carbolic fuchsin, disebelah kiri guru mitra adalah salah satu mahasiswa pendidikan Biologi yang turut serta dalam tim pengabdian sedang memantau pembuatan preparat. D. Pengamatan konfigurasi (perilaku) kromosom subfase diploten dan diakinesis dilakukan pada perbesaran $1000 x$

Keterlibatan guru mitra dalam preparasi sediaan sel-sel folikel untuk pengamatan profase I meiosis dan visualisasinya sangat tinggi. Keterlibatan yang tinggi ini ditunjukkan dengan partisipasi aktif mereka dalam merampungkan tugas pembuatan preparat squash sel-sel folikel untuk pengamatan profase I meiosis dan semua peparat yang dihasilkan selalu dimintakan verifikasi pada tim pengabdian. Penugasan praktikum yang dilakukan guru-guru mitra dalam pelatihan ini adalah (1) praktik teknik koleksi dan penyimpanan folikel testis, (2) praktik teknik isolasi sel-sel folikel pada testis jangkrik Gryllus campestris, (3) praktik teknik squash sel-sel folikel untuk pembuatan peparat subfase profase I meiosis, (4) praktik observasi struktur khas konfigurasi kromosom pada subfase leptoten, zigoten, pakiten, diploten dan diakinensis dibawah mikroskop, dan (5) praktik 


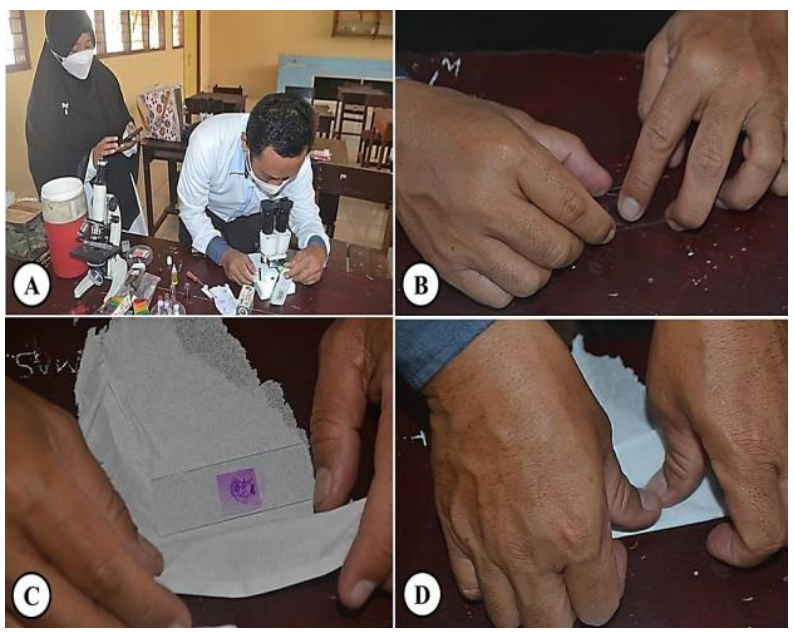

Gambar 2. Kegiatan penyiapan folikel dan pembuatan preparat squash. A. Guru mitra sedang melakukan praktek isolasi kumpulan sel-sel folikel testis Gryllus campestris dibawah mikroskop bedah. B. Peletakan gelas penutup diatas gelas benda yang berisi kumpulan sel-sel folikel. C. Proses squashing (pemencetan) folikel Gryllus campestris. D. Preparat squash yang siap diamati dibawah mikroskop

visualisasi (pengambilan foto) kromosom subfase leptoten, zigoten, pakiten, diploten dan diakinensis dibawah mikroskop.

Pembuatan preparat kromosom meiosis mengacu pada petunjuk yang memuat garis-garis besar prosedur preparasi dan squashing sel-sel folikel Gryllus campestris. Kegiatan awal yang dilakukan pada pembuatan preparat meiosis adalah menyediakan testis yang diambil dari jangkrik Gryllus campestris jantan. Testis jangkrik berukuran sangat besar sehingga mudah menemukan organ tersebut dalam abdomen. Testis yang telah dikeluarkan dimasukkan dalam larutan fiksatif campuran alkohol absolut dan asam asetat glasial dengan perbandingan 3:1 selama 1 jam. Isolasi folikel dilakukan pada testis yang diletakkan di atas gelas benda dibawah mikroskop bedah. Pemotongan folikel dengan silet dan pengambilan menggunakan kuas.

Hasil pengamatan selama pelatihan menunjukkan bahwa isolasi folikel menggunakan kuas untuk dipindahkan ke slide lain seringkali menyebabkan folikel yang berukuran kecil tersebut berlekatan kuat dengan rambut-rambut kuas sehingga menyulitkan dalam pengambilan. Ada dua langkah yang dilakukan untuk mengatasi kendala ini, yaitu folikel dipindahkan menggunakan kuas yang dikuangi rambut-rambutnya atau folikel tetap pada slide tersebut dan testis yang dipindahkan.
Dalam perjalanan praktikum, langkah kedua lebih efektif. Folikel pada gelas benda ditetesi pewarna carbolic fuchsin untuk selanjutnya dilakukan squashing.

Jumlah folikel yang digunakan dalam pembuatan preparat squash menghasilkan sebaran kromosom yang berbeda-beda. Guru mitra yang menggunakan 2-3 folikel menghasilkan sebaran kromosom yang lebih bagus dibandingkan dengan yang menggunakan jumlah diatas 3 folikel. Hal ini disebabkan karena semakin banyak folikel digunakan poses squashing menjadi semakin sulit sehingga menghasilkan preparat yang tebal dan kromosom yang kurang tersebar. Untuk mengatasi kondisi tersebut, beberapa guru mitra mencoba mengetuk gelas penutup menggunakan ujung gagang kuas sebelum squashing (pemencetan), namun hal ini berakibat sel-sel banyak yang pecah dan kromosom terpisah dari kelompoknya.

Guru mitra yang mencoba memisahkan jaringan yang berisi sel-sel folikel untuk pembuatan preparat menghasilkan sebaran kromosom preparat squash yang paling bagus. Karena cara ini menghasilkan sediaan yang bagus, maka guru mitra harus meningkatkan kecermatan dengan berlatih melakukan isolasi sel-sel folikel dibawah mikroskop bedah secara berulang-ulang. Berkat keseriusan dalam latihan dan pendampingan dari tim pengabdian, semua guru mitra menjadi familiar dan tampil melakukan isolasi sel-sel folikel. Kendala yang dihadapi pada penggunaan kumpulan sel-sel folikel (sel-sel induk sperma) untuk pembuatan preparat meiosis adalah pada saat sel-sel induk sperma yang berukuran kecil tersebut ditetesi (terendam) pewarna, akan sulit mengontrol posisi sel-sel untuk tetap berada di tengah karena tertutup warna pewarna yang pekat dan demikian pula ketika ditutup dengan gelas seringkali kumpulan sel-sel bergerak menuju sisi gelas penutup sehingga menyulitkan dalam squashing. Untuk mengatasi kendala teknis ini pewarnaan tidak dilakukan pada hasil isolasi sel-sel folikel, namun dilakukan pada testis. Testis yang telah diwarnai disimpan dalam air. Sel-sel folikel (sel induk sperma) yang telah terwarna tidak perlu ditetesi pewarna yang pekat atau dapat ditetesi asam asetat $45 \%$ dan gliserin sehingga mudah dikontrol posisinya untuk tetap berada di tengah gelas benda.

Dengan kerja tekun dan bimbingan yang diberikan tim pengabdian guru-guru mitra semakin trampil membuat preparat komosom meiosis yang 
menunjukkan sebaran kromosom yang tidak tumpang tindih. Preparat yang bagus dibuat semi pemanen agar dapat bertahan cukup lama sehingga bisa digunakan beberapa kali dalam paktikum genetika di sekolah. Selanjutnya, dengan adanya preparat squash meiosis yang bagus guru mitra dapat dengan mudah melakukan determinasi masing-masing subfase yang termasuk dalam profase I meiosis. Begitu pula perilaku khas kromosom khususunya diploten dan diakinensis tergambar dengan jelas.

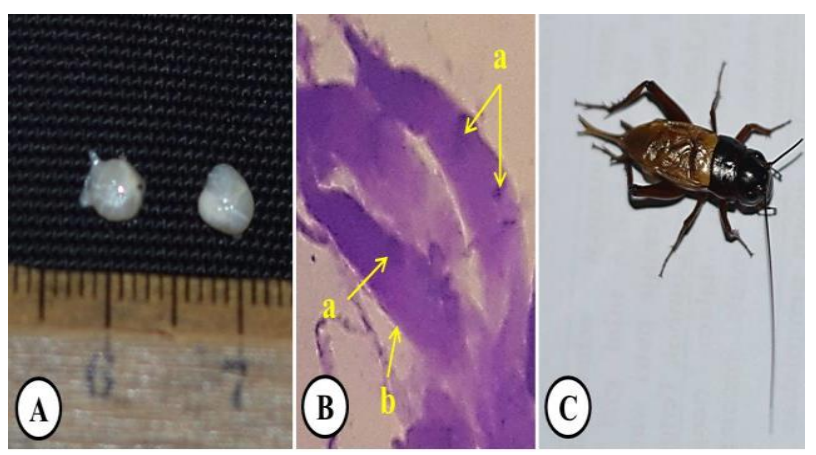

Gambar 3. Bahan pembuatan preparat kromosom meiosis. A. Testis yang telah dikeluarkan dari tubuh Gryllus campestris.B. Morfologi folikel Gryllus campestris yang diwarnai carbolic fuchsin dibawah mikroskop bedah: a = jaringan yang berisi sel-sel yang melakukan meiosis; $\mathrm{b}=$ dinding folikel. C. Individu jangkrik Gryllus campestris.

Pengamatan struktur detail meiosis fase profase I yang mencakup lima subfase dilakukan peserta pelatihan dibawah mikroskop cahaya pada perbesaran kuat. Dengan pengamatan preparat yang mereka buat sendiri, guru mitra dapat menyebutkan ciri-ciri leptoten, zigoten, pakiten, diploten, dan diakinensis dengan mudah dan benar. Visualisasi pada Gambar 4 menunjukkan bahwa pada leptoten tampak adanya manik-manik yang menggambarkan penebalan benang-benang sebagai kromomer, kromosom yang melakukan perpasangan (sinapsis) tampak jelas pada zigoten, pertautan kromosom karena pindah silang (crossing over) tampak jelas pada subfase diploten, diakinensis yang merupakan tahap akhir profase I dicirikan oleh kromosom yang memendek dan menebal dengan pertautan yang khas. Deskripsi yang dilakukan guru-guru mitra terhadap konfigurasi kromosom subfase profase I meiosis ini didukung Turkoglu et al. (2003), Lamborot dan Alvarez-Sarret (1984), Jones dan Rickards (1991). Pertanyaan yang diajukan peserta pelatihan dari hasil pengamatan konfigurasi kromosom tersebut adalah "Apa yang mengikatkan kromosom homolog sehingga bisa terjadi sinapsis?" Pernyataan yang disampaikan tim pengabdian adalah "Sinapsis terjadi karena adanya protein yang disebut synaptonemal complex (SC) yang menyatukan kromosom homolog. Protein ini juga mempunyai peran dalam mediasi terjadinya rekombinasi antar lengan kromosom pada subfase pakiten".

Pengamatan dan analisis struktur detail kromosom subfase diploten menambah wawasan berhaga guru mitra tentang proses terjadinya pindah silang (crossing over). Kiasmata yang menunjukkan tempat terjadinya crossing over tampak jelas pada diploten. Pertanyaan yang diajukan peserta sehubungan dengan subfase diploten yaitu "Mengapa kiasmata tampak pada diploten? Jawaban yang diberikan tim pengabdian adalah "Kiasmata (tempat terjadinya pindah silang) tampak jelas pada diploten karena pada subfase ini protein synaptonemal complex (SC) menghilang sehingga komosom homolog memisahkan diri kecuali pada kiasmata".

Visualisasi kromosom profase I meiosis yang mencakup lima subfase dilakukan dibawah mikroskop cahaya dengan pemasangan perangkat khusus dan tanpa perangkat khusus. Pengambilan foto kromosom pada pelatihan ini semuanya dilkukan mengunakan kamera handphone. Visualisasi dengan menggunakan kamera tanpa perangkat khusus telah dijelaskan Mertha et al. (2020). Teknik pengambilan foto menggunakan handphone dengan perangkat khusus dilakukan dengan pemasangan microscope phone holder. Alat ini dipasang pada lensa okuler mikroskop. Handphone dipasang pada alat ini, kemudian dikakukan pengaturan fokus. Dalam melakukan penataan alat ini diupayakan agar bidang pandang mikroskop tampak penuh pada layar handphone. Visualisasi yang ditunjukkan pada Gambar 4 diambil menggunakan handphone dengan bantuan perangkat microscope phone holder. 


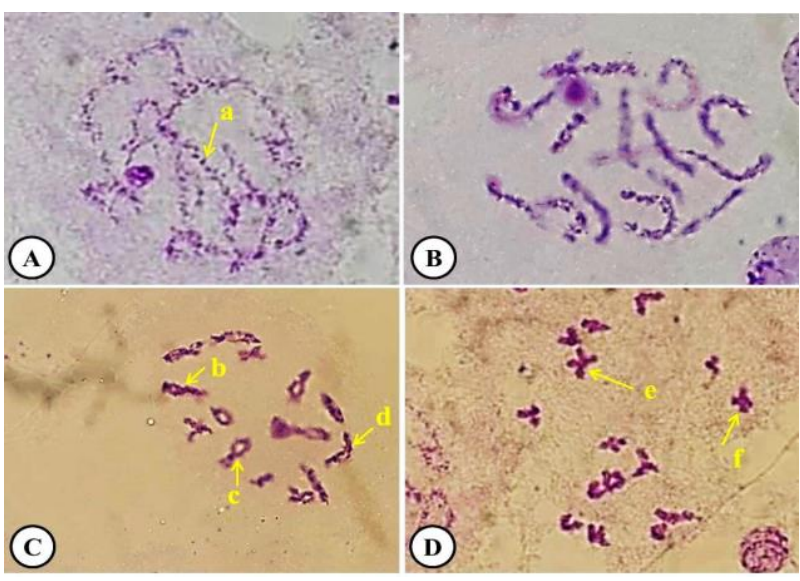

Gambar 4. Visualisasi subfase profase I meiosis hasil kerja praktik guru-guru mitra pada perbesaran 1000x dibawah mikroskop cahaya. A. Leptoten, B. Zigoten, C. Diploten, D. Diakinensis. $\mathrm{a}=$ kromomer (nukleosom); $\mathrm{b}$, $\mathrm{c}, \mathrm{d}=$ kiasmata; $\mathrm{e}, \mathrm{f}=$ konfigurasi $\mathrm{CH} 1$.

Gambar kromosom profase I meiosis Gryllus campestris yang dihasilkan dalam pengabdian ini dapat menjadi media pembelajaran yang sangat berguna untuk menunjang pembelajaran genetika. Untuk memahami materi pindah silang, pembentukan gamet tipe parental dan gamet tipe rekombinan, deteksi hibrid, dan aberasi kromosom dapat dijelaskan dengan melakukan uji konfigurasi kromosom meiosis pada zigoten, pakiten, diploten dan diakinensis. Visualisasi penyimpangan konfigurasi kromosom pada subfase tersebut dapat menjadi bioindikator terjadinya perubahan atau kerusakan genetik organisme.

\section{Kesimpulan}

Berdasarkan pengabdian pada masyarakat yang telah dilaksanakan dapat disimpulkan sebagai berikut: (1) Pengabdian ini memberikan keterampilan sangat berharga bagi guru mitra dalam pembuatan preparat squash sel-sel folikel untuk pengamatan konfigurasi kromosom subfase profase I meiosis dan teknik visualisasinya dibawah mikroskop, (2) Kerja keras dan keseriusan guru mitra sangat mendukung kelancaran praktik pembuatan perangkat pembelajaran preparat squash sel-sel folikel testis, dan (3) Keterampilan yang diperoleh guru mitra dan preparat yang dihasilkan dari pelatihan ini meupakan modal berhaga untuk perencanaan dan pelaksanaan praktikum siswa pada materi genetika di sekolah.

\section{Ucapan Terima Kasih}

Terima kasih kepada Universitas Mataram yang telah memberikan dukungan moral dan material terhadap terlaksananya kegiatan pengabdian kepada masyarakat ini. Terimakasih disampaikan juga kepada bapak Drs. Zulkarnain selaku Kepala Sekolah SMA Negeri 1 Labuapi yang telah memberikan kesempatan dalam pelaksanaan pengabdian ini.

\section{Daftar Pustaka}

Corebima, D. 2009. Pengalaman Berupaya menjadi Guru Profesional. Pidato Pengukuhan Guru Besar dalam Bidang Genetika pada Fakultas MIPA Universitas Negeri Malang, Malang, 30 Juli.

Darlington, C.D. dan L. F. La Cour, 1960. The Handling of Chromosomes. George Allen \& Unwin Ltd. London.

Fauzi, A. dan A. D. Corebima. 2016. Pemanfaatan Drosophila melanogaster sebagai organisme model dalam mengungkap berbagai fenomena rasio Mendel. Prosiding Seminar Nasional Biologi 2016, ISBN: 9786020951119.

Hayat, M. S., S. Anggraeni, dan S. Redjeki. 2011. Pembelajaran Berbasis Praktikum pada Konsep Invertebrata untuk Pengembangan Sikap Ilmiah Siswa. Bioma, Vol. 1 , No. 2: 141-152.

Jahier, J., A. M. Checre, F. Eber, R. Delourne, dan A. M. Tanguy. 1996. Terchniques of Plant Cytogenetics. Science Publishers, Inc., Lebanon.

Jones, R. N. dan C. K. Rickards. 1991. Practical Genetics. John Wiley \& Sons. New York.

Kimball, J.W. 1998. Biologi. Erlangga. Jakarta.

Lamborot, M. dan E. Alvarez-Sarret. 1984. The chromosomes of Gryllus field cricket populations in central Chile (Insecta: Grylloptera: Gryllidae). . Can. J. Zool. (63): 2626- 2631.

Mahfudhillah, H.T., S. Zubaidah, dan E. Suarsini. 2014. Pengembangan Media Genetik Box Pada Materi Genetika Kelas XII. Seminar Nasional XI Pendidikan Biologi FKIP UNS.

Mertens, T.R. dan R. L, Hammersmith. 2001. Genetics Laboratory Investigations. Twelfth Edition. Princte Hall. Upper Saddle River. New Jersey. 
Mertha, I.G., A. Al Idrus, S. Bahri, P. Sedijani, dan D.A.C. Rasmi. 2019. Pelatihan teknik pembuatan preparat squash ujung akar untuk pengamatan kromosom pada guru-guru biologi di Kota Mataram. Jurnal Pendidikan dan Pengabdian Masyarakat, November 2019, Vol. 2, No. 4: 454 459.

Mertha, I.G., S. Bahri, L. Zulkifli, A. Ramdani, dan N. Lestari. 2019. Pelatihan pembuatan preparat kromosom dan peyusunan karyotipe di Fakultas Mipa program studi Biologi Universitas Islam AlAzhar Mataram. Jurnal Pengabdian Magister Pendidikan IPA 2019, (2) 1: 75-78.

Nirmalasari, L. 2013. Pengaruh Kegiatan Pembelajaran Biologi Berbasis Praktikum Terhadap Peningkatan Keterampilan Generik Siswa Pada Pokok Bahasan Gerak Pada Tumbuhan di SMP Negeri 1 Ciawigebang Kabupaten Kuningan. Skripsi. Institut Agama Islam Negeri Syekh Nurjati Cirebon Jawa Barat.

Nusantari, E. Dan A. Abdul. 2013. Kajian Miskonsepsi Genetika Yang Ditemukan pada Bahan Ajar Biologi SMA dan Perbaikan Kesalahan Konsep Genetika. Laporan Penelitian Penelitian Fundamental. Universitas Gorontalo.

Rahman, T., N. Y. Rustaman, N. S. Sukmadinata, dan A. Poedjaji. 2004. Program Pembelajaran Praktikum Berbasis Kemampuan Generik (P3BKG) dan Profil Pencapaiannya. Hal 1-17.

Roini, C. 2013. Organisasi konsep genetika pada buku biologi SMA kelas XII. Jurnal EduBio Tropika, Volume 1, Nomor 1, Oktober 2013: 1-60.

Rondonuwu, L. E. P. S. 1989. Dasar-Dasar Genetika. Departemen Pendidikan dan Kebudayaan. Direktorat Jendral Pendidikan Tinggi. Proyek Pengembangan Lembaga Pendidikan Tenaga Kependidikan, Jakarta.

Singh, R.J. 1993. Plant Cytogenetics. CRC Press. Lodon.

Suryo, 1995. Sitogenetika. Gajah Mada University Press. Yogyakarta.

Turkoglu, S., S. Koca, dan N. Akpinar. 2003. Karyological observations on Gryllus campestris L. (Gryllidae, Orthoptera). Zoology in the Middle East (28): 113-117.

Woelaningsih, S.1999. Struktur dan Perkembangan Tumbuhan II. Laboratorium Anatomi Tumbuhan. Fakultas Biologi. Universitas Gadjah Mada. Yogyakarta. 